\title{
PENGARUH LATIHAN DOUBLE LEG CONE HOP DAN LUNGES TERHADAP HASIL TENDANGAN LONG PASS PEMAIN SSB INTERNAL FC U-19
}

\author{
Kartika Septianingrum $^{1 *}$, Kuncoro Darumoyo ${ }^{2}$ Priagung $^{3}$, HS Muhammad Nurfatony ${ }^{4}$, \\ Mohammad $\operatorname{Irfan}^{5}$ \\ 1,2,3,4,5 STKIP Modern Ngawi, Indonesia, \\ kartikasept08@stkipmodernngawi.ac.id, kuncorodarumoyo@stkipmodernngawi.ac.id, \\ priagung1@yahoo.com,muhammad.nurfatonni@gmail.com, ifanpansa123@gmail.com
}

\begin{abstract}
This study aims to determine the effect of the practice of duoble leg cone hops and lunges on the level of long pass ability of SSB Internal FC soccer players, Ngawi. This study uses an experimental method with a "three groups pre-test-post-test design" design. The population in this study were football players from SSB Internal FC, Ngawi, which amounted to 30 people. Data analysis used t-test with a significance level of 5\%. The results showed that (1) There was a significant effect of double leg cone hop exercise on the level of long pass strength of SSB Internal FC soccer players, Ngawi, with $t$ count $-14.230>t$ table 2.447 , and a significance value of $0.000<0.05$, and a percentage increase of $8.69 \%$. (2) There is a significant effect of lunges training on the level of long pass strength of SSB Internal FC soccer players, Ngawi, with $\mathrm{t}$ count $-5,161>\mathrm{t}$ table 2.447 , and a significance value of $0.001<0.05$, and a percentage increase of $5.94 \%$. (3) The duoble leg cone hop exercise was better than the lunges exercise on the strength level of the SSB Internal fc soccer player, Ngawi, with t count $2.753>$ $\mathrm{t}$ table $=2.365$ and sig, $0.022<0.05$.
\end{abstract}

Keywords: double leg cone hop, lunges, long pass strength

ABSTRAK. Penelitian ini bertujuan untuk mengetahui pengaruh latihan duoble leg cone hop dan lunges terhadap hasil tendangan long pass pemain sepak bola SSB Internal FC, Ngawi. Penelitian ini menggunakan metode eksperimen dengan desain "three groups pre-test-post-test design". Analisis data menggunakan uji $\mathrm{t}$ taraf signifikansi 5\%. Hasil penelitian menunjukkan bahwa (1) Ada pengaruh yang signifikan latihan double leg cone hop terhadap hasil tendangan long pass pemain sepak bola SSB Internal FC, Ngawi, dengan $t$ hitung $-14,230>t$ tabel 2,447 , dan nilai signifikansi $0,000<0,05$, dan kenaikan persentase sebesar 8,69\%. (2) Ada pengaruh yang signifikan latihan lunges terhadap hasil tendangan long pass pemain sepak bola SSB Internal FC, Ngawi, dengan $t_{\text {hitung }}-5,161>t$ tabel 2,447, dan nilai signifikansi 0,001 $<0,05$, dan kenaikan persentase sebesar 5,94\%. (3) Latihan duoble leg cone hop lebih baik daripada latihan lunges terhadap tingkat kekuatan tendangan long pass pemain sepak bola SSB Internal FC Ngawi, dengan $t_{\text {hitung }} 2,753>t_{\text {tabel }}=2,365$ dan sig, 0,022 $<0,05$.

Kata kunci: double leg cone hop, lunges, kekuatan tendangan long pass

\section{PENDAHULUAN}

Olahraga telah menjadi salah satu gaya hidup yang tidak dapat dipisahkan dari masyarakat, menurut Jonasson (2013:11) menyatakan bahwa olahraga merupakan performa bentuk partisipasi aktivitas fisik yang terorganisir, bertujuan mengekspresikan 
atau meningkatkan kebugaran fisik dan kesejahteraan mental, membentuk hubungan sosial atau memperoleh hasil dalam kompetisi di semua tingkatan.

Sepak bola adalah permainan yang sangat populer, karena permainan sepak bola sering dilakukan oleh anak-anak, orang dewasa maupun orang tua. Saat ini perkembangan permainan sepak bola sangat pesat sekali (Yanuar, 2012). Sepak bola adalah olahraga yang membina dan mengembangkan olahragawan secara terencana, berjenjang, dan berkelanjutan melalui kompetisi untuk pencapaian keterampilan sepak bola dengan dukungan ilmu pengetahuan dan teknologi keolahragaan, dari pernyataan di atas pembinaan olahraga keterampilan sepak bola yang menyangkut aspek fisik, teknik, psikis perlu lebih diperhatikan sebab keberhasilan pembinaan atlet junior akan berdampak pada keterampilan sepak bola atlet tersebut pada suatu hari nanti.

Pada permainan sepak bola, seorang pemain bukan hanya dituntut untuk mempunyai fisik, teknik, taktik serta mental yang kuat, akan tetapi setiap pemain juga harus mempunyai keterampilan teknik dasar permainan yang baik dan benar. Passing merupakan salah satu teknik dasar dalam permainan sepak bola yang dilakukan dengan cara menendang bola ke sasaran yang telah di tentukan dan harus dikuasai oleh seorang pemain karena ketrampilan tersebut (tendangan) membantu dalam membangun serangan ke arah pertahanan lawan dan sekaligus menciptakan peluang gol. Hasanah (dalam Maulana, 2016, hlm. 32) mengemukakan bahwa "Passing adalah teknik memindahkan momentum bola dari satu pemain ke pemain lain". Dimana ada passing yang bolanya menyusur tanah dan ada passing yang bolanya melambung. Passing dapat dikategorikan menjadi dua bagian yaitu passing lambung dan passing datar (bawah menyusur tanah). Passing lambung (long passing) sering digunakan saat melakukan umpan bola dari samping dan tendangan bebas saat terjadi di lapangan tengah.

Iskandar et al., (2020) menyatakan bahwa menendang bola atas atau lambung sering dilakukan saat adanya pelanggaran di lapangan tengah, umpan bola dari samping, tendangan pojok. Pada dasarnya menendang dengan menggunakan punggung kaki bagian dalam digunakan untuk mengumpan jarak jauh. Berdasarkan dari definisi tersebut long pass adalah tendangan yang jaraknya jauh dengan tujuan untuk membuang bola dari serangan lawan dan memberi umpan jauh kepada teman satu tim yang berada di depan untuk melakukan serangan secepat mungkin ke daerah pertahanan lawan. Menurut 
(Wasistiono et al., 2020) menyatakan bahwa gerakan menendang bola dalam kinesiologi termasuk gerakan rotasi atau gerakan anguler (berputar). Ada 14 Gerakan berputarnya adalah berputarnya tungkai bawah pada sendi lutut dan berputarnya paha pada sendi pinggul dimana jarak yang ditempuh berupa busur lingkaran. Dalam hal ini segmensegmen tubuh yang bergerak (kaki ayun) merupakan radius lingkaran. Pada permainan sepak bola teknik tendangan long pass merupakan salah satu tendangan yang dibutuhkan oleh sebagian anggota tim sepak bola, terutama pemain belakang.

Harsono dalam Iskandar et al., (2020) menyatakan bahwa pelatihan adalah proses yang sistematis dari berlatih atau bekerja, yang dilakukan secara berulang-ulang dengan kian hari kian menambah beban latihan atau pekerjaannya. Latihan akan dilakukan secara sistematis dan terstruktur untuk mempersiapkan performa dalam menghadapi pertandingan.

\section{Prinsip-prinsip Pelatihan}

Menurut Harsono dalam Iskandar et al., (2020) menyatakan bahwa prinsip latihan adalah prinsip-prinsip yang amat mendasar akan tetapi penting dan yang dapat diterapkan pada setiap cabang olahraga. Prinsip-prinsip ini harus benar-benar diketahui dan dimengerti oleh pelatih maupun atlet. Prinsip-prinsip pelatihan meliputi: (1) Prinsip beban lebih, (2) Prinsip spesialisasi, (3) Prinsip Individualisasi, (4) Intensitas latihan, (5) Kualitas latihan, (6) Prinsip variasi, (7) Prinsip pulih asal.

\section{Aspek-aspek Pelatihan}

Harsono dalam Iskandar et al., (2020) menyatakan bahwa tujuan serta sasaran utama dari latihan atau training adalah untuk membantu atlet untuk meningkatkan keterampilan dan prestasinya semaksimal mungkin. Untuk mencapai tujuan dari latihan ada beberapa aspek latihan yang perlu diperhatikan yaitu latihan fisik, latihan teknik, latihan taktik, dan latihan mental.

\section{Latihan Double Leg Cone Hop}

Latihan Double Leg Cone Hop yaitu lompat kedepan dengan kedua tungkai melewati rintangan yang berbentuk cone atau segitiga (Chu et al., 2006). Mekanisme latihan Double Leg Cone Hop dapat meningkatkan kemampuan tendangan melambung jauh dilihat dari proses fisiologis dalam tubuh atlet yang berubah. Tubuh memiliki propioceptor atau reseptor yang sensitif terhadap ketegangan dan peregangan. Muscle spindle salah satu dari 
propioseptor yang berperan aktif dalam gerak stretch reflex. Stretch reflex adalah respons yang tidak disadari berupa kontraksi melalui stimulus dari luar yang menyebabkan otot terulur. Secara praktik dapat dikatakan bahwa dengan lebih cepat dan kuat suatu gerak yang diterapkan di otot, maka gerakan yang lebih bertenaga saat kontraksi otot akan muncul (Kutz, 2010).

Adaptasi fisiologis yang dinyatakan sebagai perubahan dalam komposisi serat otot, dilaporkan dihasilkan melalui respons neuromuskuler disebut sebagai Stretch-8 Shortening Cycle (SSC) (MacLean, 2010). Stretch-Shortening Cycle (SSC) melibatkan menyimpan energi potensial di otot memanjang. Tahap 1 dari SSC dikenal sebagai fase eccentric di mana prapembebanan dan peregangan otot terjadi. Kontraksi eccentric menjadi dasar dalam perubahan lingkungan lokal otot untuk menyokong perkembangan sensitivitas otot pada motor neuron dan motor unit yang selanjutnya menjadi keberhasilan pemusatan produksi power saat fase konsentrik.

Tahap II SSC adalah fase amortisasi. Amortisasi (atau transisi). Maka kesimpulannya adalah waktu yang baik antara mendarat dan melompat lagi. Fase amortisasi adalah tahap yang paling penting dan harus dijaga pendek. Semakin lama amortisasi fase semakin besar kehilangan energi elastis yang tersimpan. Fase ini kontraksi yang terjadi adalah kontraksi isometrik, kontraksi ini terjadi saat seorang secara jelas berkontraksi tetapi tidak terjadi perubahan tonus atau tetap, dalam fase ini energi elastis yang telah diproduksi dan disimpan saat fase eccentric akan mulai dikirim secara keseluruhan dalam fase ini perkembangan kemampuan otot tidak terjadi tetapi peningkatan power saat derajat sendi yang digunakan akan disesuaikan penggunaannya saat fase konsentrik (Kraemer et al., 2001). Kontraksi otot yang tetap terjadi sekitar 5 detik ini memberikan tekanan pembuluh darah yang memberikan perintah pengiriman dan pengeluaran tenaga elastis kumpulan sintesa energi dalam aliran darah ke otot yang siap mengeluarkan gerak meledak secara cepat (Kutz, 2010).

Tahap III dan terakhir SSC adalah tahap konsentris, di mana energi elastis tersimpan dikombinasikan dengan kontraksi otot volunter, konsentris berkontribusi untuk memberikan kekuatan yang diperlukan untuk gerakan berikutnya, atau melompat (Kutz, 2010). Kemudian pengeluaran tenaga maksimal tersebut terjadi, kontraksi ini merupakan fase penutup dari kedua fase yang terjadi sebelumnya, semua urutan proses ini tidak dapat 
terpisahkan dan menjadi satu kompleks kontrol untuk menghasilkan power yang maksimal dan proses ini dipengaruhi oleh waktu yang tepat, keharmonisan gerakan dan ketepatan gerakan (Kutz, 2010).

\section{Latihan Lunges}

Menurut Sumarsono (2009: 20), latihan pembentukan otot kaki sangat dibutuhkan karena menyangkut daerah otot yang sangat luas. Salah satu latihan yang tepat yaitu latihan Lunges. Latihan ini memperkuat paha belakang dan otot gluteal dan meningkatkan kontrol gerakan. Menurut Baechle, dkk, (2000: 138) Latihan lunge merupakan suatu bentuk latihan untuk membentuk kekuatan otot tungkai atau latihan pembentukan kaki atas. Secara fisik latihan ini sangat dibutuhkan karena menyangkut daerah otot yang luas. Latihan lunge ini dilakukan dengan beban bebas, dan relatif sulit dalam melakukan lunge, karena diperlukan keseimbangan. Walking Lunges adalah gerakan melangkah kedepan dengan menekukkan salah satu kaki sebagai tumpuan, dan membentuk sudut $90^{\circ}$ kaki depan maupun kaki yang belakang, dengan posisi tubuh tegak lurus dan kedua tangan di bawah.

Lunges merupakan latihan kaki yang melibatkan otot paha depan, paha belakang, pantat dan betis. Lunges adalah pembangun kekuatan yang bagus untuk siapa pun, tak hanya mereka yang mendalami dunia body building, namun semua orang mulai dari pelari hingga pembalap sepeda. Ini adalah salah satu latihan yang paling penting untuk paha dan bokong. Cara Melakukan Walking Lunges sebagai berikut :

a. Mulailah dengan berdiri tegak

b. Ambil langkah panjang ke depan dengan kaki kanan (mendarat dengan tumit kaki kanan terlebih dahulu)

c. Tekuk kedua lutut sehingga lutut kanan sejajar atas, pergelangan kaki dan lutut kiri mendekati lantai

d. Angkat tumit kanan dari lantai, ambil langkah panjang ke depan dengan kaki kiri sementara kaki kanan tahan dengan posisi lutut hampir menyentuh lantai

\section{METODE PENELITIAN}

Metode yang digunakan dalam penelitian ini adalah kuantitatif dengan metode eksperimen. Desain yang digunakan dalam penelitian ini adalah "Three Groups Pretest- 
Posttest Design". Teknik pengumpulan data yang di pakai dalam penelitian ini diadakan tes awal yaitu melakukan pretest dan tes akhir (posttest). Sampel dalam penelitian ini adalah pemain sepak bola SSB Internal FC, Ngawi yang diambil menggunakan teknik total sampling. Teknik pembagian sampel yang dilakukan dalam penelitian ini yaitu dengan menggunakan ordinal pairing. Ordinal pairing adalah pembagian kelompok menjadi tiga dengan tujuan keduanya memiliki kesamaan atau kemampuan yang merata, (Sugiyono, 2007:61). Instrumen penelitian ini menggunakan teknik Barrow yaitu teknik menendang bola yang digunakan untuk mengukur teknik tendangan long pass Penelitian ini akan diuji normalitas dan uji homogenitas data. Sebelum melangkah ke uji-t, ada persyaratan yang harus dipenuhi oleh peneliti bahwa data yang dianalisis harus berdistribusi normal, untuk itu perlu dilakukan uji normalitas dan uji homogenitas (Arikunto, 2006: 299).

\section{HASIL DAN PEMBAHASAN}

\section{Hasil Penelitian}

\section{Deskripsi Data Hasil Penelitian}

Hasil penelitian kekuatan tendangan jarak jauh pemain sepak bola SSB INTERNAL FC, Ngawi kelompok latihan Double Leg Cone Hop, Lunges dan kontrol dideskripsikan sebagai berikut:

a. Pretest dan Posttest Kekuatan Tendangan Jarak Jauh Kelompok Double Leg Cone Hop

Hasil penelitian untuk hasil pretest nilai minimal $=26.84$, nilai maksimal $=41.80$, rata-rata $=35.199$, simpang baku $=4.43$, sedangkan untuk posttest nilai minimal $=38.97$, nilai maksimal $=45.84$, rata-rata $=38.148$, simpang baku $=4.82$ Hasil selengkapnya sebagai berikut:

Tabel 1. Hasil Pretest dan Posttest Kekuatan Tendangan Jarak Jauh Kelompok Latihan Double Leg Cone Hop

\begin{tabular}{lll}
\hline & \multicolumn{1}{c}{ Pretest } & \multicolumn{1}{c}{ Posttest } \\
\hline Mean & 35.199 & 38.148 \\
SD & 4.430559 & 4.823765 \\
Min & 26.84 & 38.97 \\
Max & 41.80 & 45.84 \\
\hline
\end{tabular}

Berdasarkan data pada tabel 4.1 di atas, pretest dan posttest kekuatan tendangan jarak jauh pemain sepak bola SSB INTERNAL FC, Ngawi menunjukkan bahwa kemampuan tendangan jarak jauh pada saat pretest mempunyai rata-rata sebesar 35,19 meter, dan 
meningkat sebesar 38,14 meter setelah diberikan latihan Double Leg Cone Hop selama 12 kali pertemuan.

\section{b. Pretest dan Posttest Kekuatan Tendangan Jarak Jauh Kelompok Lunges}

Hasil penelitian untuk hasil pretest nilai minimal $=28.37$, nilai maksimal $=41.44$, rata-rata $=35.16$, simpang baku $=4,18$, sedangkan untuk posttest nilai minimal $=27.23$, nilai maksimal $=22.30$, rata-rata $=37,05$, simpang baku $=4,80$. Hasil selengkapnya sebagai berikut:

Tabel 2. Hasil Pretest dan Posttest Kekuatan Tendangan Jarak Jauh Kelompok Latihan Lunges

\begin{tabular}{lll}
\hline \multicolumn{1}{c}{ Nama subjek } & \multicolumn{1}{c}{ pretest } & \multicolumn{1}{c}{ Posttest } \\
\hline Mean & 35.161 & 37.052 \\
SD & 4.185949 & 4.803244 \\
Min & 28.37 & 27.23 \\
Max & 41.44 & 44.30 \\
\hline
\end{tabular}

Berdasarkan data pada tabel 4.2 tersebut di atas, pretest dan posttest kemampuan tendangan jarak jauh pemain sepak bola SSB INTERNAL FC, Ngawi menunjukkan bahwa kemampuan tendangan jarak jauh pada saat pretest mempunyai rata-rata sebesar 35,16 meter, dan meningkat sebesar 37,05 meter setelah diberikan latihan Lunges (B) selama 12 kali pertemuan.

c. Pretest dan Posttest Kekuatan Tendangan Jarak Jauh Kelompok kontrol

Hasil penelitian untuk hasil pretest nilai minimal $=29.56$, nilai maksimal $=41.23$, rata-rata $=35.28$, simpang baku $=4,03$, sedangkan untuk posttest nilai minimal $=29.97$, nilai maksimal $=42.03$, rata-rata $=36.10$, simpang baku $=4,03$. Hasil selengkapnya sebagai berikut:

Tabel 3. Hasil Pretest dan Posttest Kekuatan Tendangan Jarak Jauh Kelompok Kontrol

\begin{tabular}{lcc}
\hline \multicolumn{1}{c}{ Nama subjek } & Pretest & Posttest \\
\hline Mean & 35.288 & 36.101 \\
SD & 4.035319 & 4.030499 \\
Min & 29.56 & 29.97 \\
Max & 41.23 & 42.03 \\
\hline
\end{tabular}

Berdasarkan data pada tabel 4.3 tersebut di atas, pretest dan posttest kemampuan tendangan jarak jauh pemain sepak bola SSB INTERNAL FC, Ngawi kelompok latihan 
Lunges menunjukkan bahwa kemampuan tendangan jarak jauh pada saat pretest mempunyai rata-rata sebesar 35,2 meter, dan meningkat sebesar 36,1 meter setelah diberikan latihan bebas (kontrol) selama 12 kali pertemuan.

\section{Pembahasan}

a. Perbandingan Pretest dan Posttest Hasil Tendangan Jarak Jauh Kelompok Latihan Double Leg Cone Hop

Hipotesis yang pertama berbunyi "Ada pengaruh yang signifikan latihan Double Leg Cone Hop terhadap tingkat kemampuan tendangan jarak jauh pemain sepak bola SSB Internal FC, Ngawi", Kesimpulan penelitian dinyatakan signifikan jika nilai t hitung $>\mathrm{t}$ tabel dan nilai sig lebih kecil dari 0.05 (Sig < 0.05). Berdasarkan hasil analisis diperoleh data sebagai berikut.

Tabel 4. Uji-t Hasil Pretest dan Posttest Kekuatan Tendangan Jarak Jauh Kelompok Latihan Double Leg Cone

\begin{tabular}{|c|c|c|c|c|c|c|}
\hline \multicolumn{7}{|c|}{ Hop } \\
\hline \multirow[t]{2}{*}{ Kel } & Rata- & \multicolumn{5}{|c|}{ t-test for Equality of means } \\
\hline & rata & $\mathrm{tht}$ & $\mathrm{t} t \mathrm{~b}$ & Sig. & Selisih & $\%$ \\
\hline Pretest & 34.600 & & & & & \\
\hline Posttest & 37.600 & 14.230 & 2,447 & 0,000 & 3,000 & $0,09 \%$ \\
\hline
\end{tabular}

Dari hasil uji-t dapat dilihat bahwa $t_{\text {hitung }}-14,230$ dan $t$ tabel (df 9) 2,447 dengannilai signifikansi $\mathrm{p}$ sebesar 0,000 . Oleh karena $\mathrm{t}_{\text {hitung }}-14,230>\mathrm{t}_{\text {tabel }} 2,447$, dan nilaisignifikansi $0,000<0,05$, maka hasil ini menunjukkan terdapat perbedaan yang signifikan. Dengan demikian hipotesis alternatif $(\mathrm{Ha})$ yang berbunyi "Ada pengaruh yang signifikan latihan Double Leg Cone Hop terhadap hasil tendangan jarak jauh pemain sepak bola SSB INTERNAL FC, Ngawi", diterima.

Berdasarkan hasil penelitian menunjukkan bahwa ada pengaruh yang signifikan latihan Double Leg Cone Hop terhadap tingkat kemampuan tendangan jarak jauh pemain sepak bola SSB INTERNAL FC, Ngawi. Besarnya peningkatan kemampuan tendangan jarak jauh setelah diberikan latihan Double Leg Cone Hop yaitu sebesar 8,69\%. Latihan Double Leg Cone Hop merupakan latihan pliometrik untuk melatih tubuh bagian bawah. Latihan ini menargetkan otot paha depan, paha belakang dan betis yang unik dari latihan ini karena betis ikut bekerja mendorong ujung kaki di awal melompat. 
Double Leg Cone Hop merupakan bentuk latihan untuk melatih dan meningkatkan dan meningkatkan komponen daya tahan, power otot tungkai. Karena daya tahan otot adalah kemampuan otot untuk melakukan kontraksi yang berturut-turut untuk waktu yang lama. Kekuatan adalah kemampuan otot untuk membangkitkan tegangan terhadap suatu tahanan. Oleh karena itu, latihan-latihan yang cocok untuk mengembangkan kekuatan adalah latihan-latihan tahanan. Latihan Double Leg Cone Hop dirancang sedemikian rupa dengan memenuhi prinsip-prinsip ilmiah latihan agar dapat dijadikan satu latihan untuk memperoleh dan meningkatkan kekuatan (strength) otot. Latihan Double Leg Cone Hop merupakan bentuk latihan untuk meningkatkan kekuatan otot tungkai.

Tentang latihan Double Leg Cone Hop yaitu salah satu bentuk latihan untuk memaksimalkan kekuatan otot tungkai seorang individu yang melakukannya. Dengan cara latihan meloncat melewati rintangan (cone) dengan lepas landas yang tepat, pendaratan yang benar dan loncatan yang untuh pada saat melakukan loncatan dengan jarak tiga sampai lima rintangan yang berjarak kurang lebih tiga kaki terpisah.

b. Perbandingan Pretest dan Posttest Hasil Tendangan Jarak Jauh Kelompok Latihan Lunges

Hipotesis yang kedua berbunyi "Ada pengaruh yang signifikan latihan Lunges terhadap tingkat kekuatan tendangan jarak jauh pemain sepak bola SSB Internal FC, Ngawi", Kesimpulan penelitian dinyatakan signifikan jika nilai t hitung $>\mathrm{t}$ tabel dan nilai sig lebih kecil dari 0.05 (Sig < 0.05). Berdasarkan hasil analisis diperoleh data sebagai berikut.

Tabel 5. Uji-t Hasil Pretest dan Posttest Kemampuan Tendangan Jarak Jauh Kelompok Latihan Lunges

\begin{tabular}{lcccccc}
\hline Kel & Rata- & \multicolumn{5}{c}{ t-test for Equality of means } \\
& rata & $\mathrm{tht}$ & $\mathrm{t} \mathrm{tb}$ & Sig. & Selisih & $\%$ \\
\hline Pretest & 34.7000 & - & & & & \\
Posttest & 36.8000 & 5,161 & 2,447 & 0.001 & 2,100 & $5,94 \%$ \\
\hline
\end{tabular}

Dari hasil uji-t dapat dilihat bahwa t hitung -5,161 dan t table (df 5) 2,447 dengan nilai signifikansi p sebesar 0,001 . Oleh karena t hitung $-5,161>t$ tabel 2,447, dan nilai signifikansi $0,001<0,05$, maka hasil ini menunjukkan terdapat perbedaan yang signifikan.Dengan demikian hipotesis alternatif $(\mathrm{Ha})$ yang berbunyi "Ada pengaruh yang 
signifikan latihan Lunges terhadap hasil tendangan jarak jauh pemain sepak bola SSB INTERNAL FC, Ngawi", diterima.

Berdasarkan hasil penelitian menunjukkan bahwa ada pengaruh yang signifikan latihan Lunges terhadap tingkat kemampuan tendangan jarak jauh pemain sepak bola SSB Internal FC, Ngawi. Besarnya peningkatan kekuatan tendangan jarak jauh setelah diberikan latihan Lunges yaitu sebesar 5,94\%. Baechle (2000: 137) latihan-latihan pembentukan kaki atas, secara fisik dianggap sangat dibutuhkan karena menyangkut daerah otot yang sangat luas. Latihan-latihan yang dipilih adalah lunge (dengan beban bebas). Menurut Baechle, (2000: 138) latihan lunge merupakan suatu bentuk latihan untuk membentuk kekuatan otot tungkai atau latihan pembentukan kaki atas. Secara fisik latihan ini sangat dibutuhkan karena menyangkut daerah otot yang luas. Latihan lunge ini dilakukan dengan beban bebas, dan relatif sulit dalam melakukan lunge, karena diperlukan keseimbangan.

c. Perbandingan Posttest Hasil Tendangan Jarak Jauh Kelompok Latihan Double Leg Cone Hop dan Lunges

Hipotesis ketiga yang berbunyi "Latihan Double Leg Cone Hop lebih baik daripada latihan Lunges terhadap tingkat kekuatan tendangan jarak jauh pemain sepak bola SSB Browidjoyo, Yogyakarta", dapat diketahui melalui selisih mean antara kelompok A dengan kelompok B. Berdasarkan hasil analisis diperoleh data sebagai berikut.

Tabel 6. Uji t Kelompok A dengan Kelompok B

\begin{tabular}{llllll}
\hline \multicolumn{1}{c}{ Kelompok } & Pesentase & \multicolumn{5}{c}{ t-test for Equality of means } \\
& & t ht & t tb & Sig. & selisih \\
\hline $\begin{array}{l}\text { Double Leg Cone Hop } \\
\text { Lunges }\end{array}$ & $8,6 \%$ & & & & \\
& $5,94 \%$ & 2,753 & 2,365 & 0,022 & 0,800 \\
\hline
\end{tabular}

Dari tabel hasil uji t di atas dapat dilihat bahwa t hitung sebesar 2,753 dan t- tabel $(\mathrm{df}=9)=2,365$, sedangkan besarnya nilai signifikansi p 0,022. Karena $\mathrm{t}$ hitung 2,753 >t tabel $=2,365$ dan sig, 0,022 <0,05, berarti ada perbedaan yang signifikan. Berdasarkan hasil analisis diperoleh nilai rerata selisih postest kelompok latihan Double Leg Cone Hop dengan rerata posttest kelompok latihan Lunges sebesar 0,800, dengan kenaikan persentase latihan Double Leg Cone Hop lebih tinggi, yaitu 8,69\%.Dengan demikian menunjukkan bahwa hipotesis (Ha) yang berbunyi "Latihan Double Leg Cone Hop lebih baik daripada 
latihan Lunges terhadap hasil tendangan jarak jauh pemain sepak bola SSB INTERNAL FC, Ngawi", diterima.

Berdasarkan hasil analisis, menunjukkan bahwa latihan Double Leg Cone Hop lebih baik daripada latihan Lunges terhadap tingkat kemampuan tendangan jarak jauh pemain sepak bola SSB INTERNAL FC, Ngawi, dengan selisih rata-rata posttest sebesar 0,80. Latihan Double Leg Cone Hop adalah salah satu bentuk latihan Power. Latihan Double Leg Cone Hop dilakukakan dengan membebani organ tubuh dengan suatu barbel atau tubuh itu sendiri. Latihan Double Leg Cone Hop di lakukan dengan menggunakan 2 kaki tumpuan, sehingga dapat merangsang otot otot extremitas inferior yaitu otot quadriceps, gastrocnemius, biceps femoris, gluteus maximus, rectus femoris untuk selalu berkontraksi dengan cepat, baik saat memanjang (eccentric) maupun memendek (concentric). Terdapat otot otot yang digunakan untuk latihan Double Leg Cone Hop yaitu quadriceps, gastrocnemius, biceps femoris, gluteus maximus, rectus femoris. Keadaan tersebut harus dipertahankan, dengan cara berlatih secara terus menerus. Di setiap pertemuan set, repetisi, frekuensi, lama latihannya selalu bertambah, sehingga dapat menimbulkan efek latihan berupa peningkatan daya ledak serta daya tahan otot quadriceps, gastrocnemius, biceps femoris, gluteus maximus, rectus femoris.

Latihan pliometrik Double Leg Cone Hop akan berpengaruh terhadap otot gluteus, gastroknemius, kuadrisep, hamstring dan fleksor hip (Radcliffe \& Farentinos, 2002). Latihan ini juga akan membentuk kemampuan unsur kecepatan dan kekuatan otot yang menjadi dasar terbentuknya daya ledak otot.

\section{KESIMPULAN}

Berdasarkan hasil analisis data, deskripsi, pengujian hasil penelitian, dan pembahasan, dapat diambil kesimpulan, yaitu:

1. Ada pengaruh yang signifikan latihan Double Leg Cone Hop terhadap tingkat kekuatan tendangan jarak jauh pemain sepak bola SSB Internal FC, Ngawi, dengan t hitung $14,230>\mathrm{t}$ tabel 2,447, dan nilai signifikansi $0,000<0,05$, dan kenaikan persentase sebesar $8,69 \%$.

2. Ada pengaruh yang signifikan latihan Lunges terhadap tingkat kekuatan tendangan jarak jauh pemain sepak bola SSB Internal FC, Ngawi, dengan $t$ hitung $-5,161>t$ tabel 2,447, dan nilai signifikansi 0,001 <0,05, dan kenaikan persentase sebesar 5,94\%. 
3. Latihan Double Leg Cone Hop lebih baik daripada latihan Lunges terhadap tingkat kekuatan tendangan jarak jauh pemain sepak bola SSB Internal FC, Ngawi, dengan $\mathrm{t}$ hitung 2,753 $>$ t tabel $=2,365$ dan sig, $0,022<0,05$.

\section{DAFTAR PUSTAKA}

Arikunto, S. (2006). Prosedur Penelitian Suatu Pendekatan Praktek. Jakarta: PT Bina Aksara.

Baechle, R T. (2000). Latihan Beban. Jakarta. PT Rajagrafindo Persada.

Barrow, R \& Woods, R. (2006). An Introduction to Philosophy of Education (4th ed.). New York: Routledge.Chu D.A. (2006). Jumping Into Plyometrics. California: Leisure Press. Champaign, Illinois.

Iskandar,et.al (2020). Pengaruh latihan double leg cone hop dan knee tuck jump terhadap peningkatan kemampuan tendangan jarak jauh dalam permainan sepakbola di ssb Bina liga u-15 kota Pemalang . Pemalang

Jonasson, Kale. (2013). Sport Has Never Been Modern. Gothenburg. Acta University Gothoburgensis.

Kraemer, W.J., and Newton, R.U. (2001). Training for Vertical Jump. Gatorade Sport Science Institute Rep. (Sports Sci Exchange).

Kutz, R., Matthew. (2010). Theoretical and Practical Issues for Plyometric Training. NSCA's Performance Training Journal.

MacLean, Eric. (2010). A Theoretical Review of Lower Body Plyometric Training and the Appropriateness for Inclusion in Athletic Conditioning Programs. School of Exercise, Biomedical, and Health Sciences, Edith Cowen University, Perth, Australia.

Radiclife J.C \& farentinous R.C. (2002). Power Training For Sport, Plyometric For Maximum Power Development. Canada: Coaching Association of Canada.

Sugiyono. (2007). Metode Penelitian Pendidikan: Pendekatan Kuantitatif, Kualitatif, Dan R \& D. Bandung: Alfabeta.

Sumarsono, Sonny. (2009). Metode Riset Sumber Daya Manusia, Jember:Graham Ilmu.

Yanuar, (2012). Pengaruh Latihan Double Leg Cone Hop Terhadap Tendangan Melambung Jauh Pada SSB New Salatiga Football Club. Skripsi sarjana, tidak diterbitkan. Universitas Muhammadiyah Surakarta, Surakarta. 